\title{
Online Teaching vs. Classroom Teaching in the Scenario of the Covid-19 Pandemic in India.
}

\author{
Divya Deevi' ${ }^{1}$, Kavi Balabrahma Chary ${ }^{2}$ \\ ${ }^{1}$ Research Scholar \& Asst. Professor in English, VNR Vignan Jyothi Institute of Engineering and Technology, Hyderabad. \\ Lecturer in English (Retired), Hyderabad \\ 1'divya.kavi0@gmail.com, ${ }^{2}$ kavibbc@gmail.com
}

\begin{abstract}
Online teaching is barely twenty years old whereas classroom teaching is hundreds of years old. The purpose of both modes is the same teaching. But they are quite different from one another in their concept, structure, application and environment. Classroom teaching ruled the education sector for a long period because there was no alternative to it. Still, it has its due role. With the introduction of computer and software technology in the education field, a new style of teaching, online teaching, has been designed. Initially, it was intended to cater to the needs of a section of software people. Job seekers and promotion aspirants have found it convenient to gain knowledge in their own or new domains in their leisure time. Slowly this has found a significant place in regular education also. But the present pandemic situation has accelerated the entry of online teaching at all levels from primary education to higher education. Students face some initial troubles. They should buy sophisticated and modern devices; they should have an internet connection and there should be an uninterrupted power supply. This has become a challenge for poor people and those living in rural areas in India. However, students pursuing higher studies in Western countries have found this mode of online teaching very useful. They need not spend a lot of money and they can continue to do part-time jobs to earn money for their studies. But this online system of education does not suit the conditions prevailing in India. Still, many students are unable to follow online classes. The authorities should think carefully before issuing guidelines, keeping in view the financial and health problems of students especially, kids. The loss of time in the academic year can be compensated in many ways. When normalcy is restored all people in the education field will again switch over to classroom teaching in toto.
\end{abstract}

Keywords

Classroom teaching, its history, invention of the internet, online teaching, advantages and disadvantages, present Covid-19 crisis- its effects.

Article Received: 10 August 2020, Revised: 25 October 2020, Accepted: 18 November 2020

\section{Introduction}

Which is the best mode of teaching- classroom or online? This question did not arise untilthe end of the twentieth century or even in the first decade of this century. If this question is posed to the people in the age groups of 40 and so, they wonder and immediately retort how instruction can be given without a classroom. The classroom concept has centuries of history, though the mode, size, structure varied from time to time. It started in the Gurukulam Ashram where saints gave instruction to a handful of students, without books and rooms. Gradually instruction in classrooms has undergone many significant changes like having organized and well-structured rooms, systematic curriculum and use of materials. Teaching mode has reached an unimaginable state with the use of technology from the age-old practice of oral teaching to online teaching. But all these improvements have occurred in classrooms under the supervision of teachers. Students are comfortable with this system of classroom teaching.

But unfortunately, the pandemic COVID-19 has brought many changes throughout the world. It has put a full stop to classroom teaching at least for a short period. It has compelled all the stakeholders- students, teachers, parents, educational institutions and the governments - to resort to online teaching, which is new to many. However online teaching is not a modern mode. It has been practised in software fields. People who want to learn new courses in software technology and who are unable to attend classrooms take online teaching. This type of online teaching is limited and restricted to a section of highly educated graduates of general education and technical education.

Dr.Sarah Glove has a Ph.D. in instructional technology. She has taught online and in-person at North Carolina University. In an interview with Keaton Robbins, she says "The students gather in physical classrooms within the facility during a certain time frame(e.g. $8 \mathrm{am}-2 \mathrm{pm})$ to learn about specific topics, subjects or get specific hands-on job training and experience". According to Dr. Sarah, in an outline format, a teacher will upload or post content on learning management software and share it with the class digitally. Some LMSs also offer live online streams where students can engage with the teacher as they instruct on the course in a live setting.

Now the situation forces all students right from nursery education to postgraduate education to accept online teaching. But, here, all academicians and higher education agencies and governments should ask themselves a question- is it necessary to impose online teaching, just to streamline the academic calendar? There is no need to be hurried in this regard. Even if the academic process is postponed to three or four months, there would be no loss to the education of students. Generally, all educational institutions are closed in April, May, and almost half a month in June. It is a general practice being followed every year. There will no problem if they are further closed by three more months. The academic year may be adjusted by cancelling some mid-year holidays and summer vacation. There were many instances in the past, especially in the 1970s, when the year-end examinations were conducted in 
July and August and consequently the next academic year was started in September or October. Now also even without the burden of online teaching for students, the academic process can be streamlined in just two years. It can be done by cancelling vacation wherever possible and by reducing the syllabus to some extent.

People, who advocate the implementation of online teaching, fail to understand the ground realities of our country. Political leaders and financial experts assert that our villages are the backbone of India. According to the article published by "The Associated Press" on 3rd July 2015 more than $70 \%$ of India's people live in villages with the majority extremely poor and depend on manual labour. This data was collected between 2013 and 2015.There may be an improvement but still, there are many villages- out of $5,90,000$ odd villages- that have no infrastructure to meet the new technological advancement. Many villages witness frequent interruptions in power supply during daytime.

Another thing necessary for online teaching is network connectivity. As per the statement made by Telecom Minister Mr. Manoj Sinha in the Lok Sabha on 01-08-2018, 43,088 villages are without mobile services. Even the villages having mobile network connectivity, are unable to get signals because of various reasons. The most important is financial problems faced by much poor and middle class. For online teaching, devices like a computer, a laptop, a television, or a smartphone are essential. In villages, a majority of people cannot afford to buy any one of these. Students from rural backgrounds form a vital part of the student community. In 2019-20 nearly 6 lakh students appeared for 10th class in A.P and all are promoted to higher classes without Public Examinations. Most of these students have come from rural areas and many of them are below the poverty line. They can't buy any of these devices to follow online teaching in their higher classes.

Because of these facts, online teaching at this juncture is not feasible or accessible to a large part of the student community. It is estimated that nearly 350 million students are studying different courses in various educational institutions across our country. When most of the students are unable to follow online teaching, the government's goal of providing education to all cannot be achieved.

Now, the drawbacks of online teaching may be discussed. Though the power problem and network problems are solved, the live webinars pose a major concern. Almost all webinars conducted by different educational and other organizations on English Language and Literature have witnessed technical glitches, some major and some other minor during the sessions; the organizers were forced to close the streaming abruptly. They were compelled to assure the participants that they would send the recorded videos of the speeches of the resource persons through Whats App groups. This caused a lot of inconvenience to the participants and made them impatient. If it is the case in respect of webinars where postgraduate students, lecturers, professors and eminent academicians attend, how can it be advisable for primary and secondary level students who have to attend online classes hours together?

The different policies being adopted by the state governments and the situation prevailing on the topic of online teaching create a lot of confusion and uncertainty among students, teachers, parents and educational institutions across the country. This is mainly seen in lowerclass students studying in primary schools. Some state governments have banned online teaching for small children, while some others have allowed limited time for such classes. However, private institutions never follow such guidelines. They argue that they have to collect fees to meet the expenditure including the salaries of teachers. There may be some justification in their argument but the resources available to students and the effects of health must be considered. Recently, in an article published in a regional daily newspaper, an ophthalmologist has warned parents about the consequences of a long-time watching smartphones regularly by children. He says that it would hinder their eyesight and create other problems.

The most important thing is no facilities are found for online teaching in elementary schools in villages and some high schools. If the benefit of online teaching is denied to those students- the basic principle of our constitution - the right to education for all - is ignored. So governments should be very cautious while taking any decision on online teaching. Another thing to be considered is the opinion of parents on the subject. Almost all parents, who were interviewed by reporters of news channels recently, firmly opposed the idea of sending their children to schools. But there were different opinions on online teaching. Some preferred it saying that it would help children to be in touch with studies. Some others opposed it on the ground that they were unable to provide cell phones to children. A few parents maintained that there would be no harm in waiting for some time on this issue.

Interestingly, teachers are divided in this matter. According to a survey conducted by a reporter of the Indian Express in Delhi, some teachers supported the concept of online teaching, while others opposed it. The opinions expressed by both these categories are equally justified. The physical and mental capacity of children must also be taken care of. It causes a lot of stress to parents especially mothers. A teacher has observed that mothers are attentive and punctual to online classes than children. They sit before cell phones with their children, feeding them, sometimes brushing them, while attending online classes. It shows anxiety and tension in parents.

Another significant thing is technology problems faced by teachers. Most of them are not computer literates. They face many problems in designing online class materials like PPTs, Audios, and Videos. They have to create their own classrooms in the Zoom, YouTube, Whats app, and Go to meeting platforms. It may be possible for teachers working in cities, but not in towns and villages. In technical courses, labs are necessary for all subjects including English. The personal involvement of students is necessary for doing laboratory experiments. It is impossible to conduct experiments with students in online teaching mode.

Of course, there are some advantages to online teaching. It provides flexibility throughout the learning process. Teachers can work on their lessons and upload course material. Students can access the material. when they find leisure time. In some countries, students have to pay a huge amount to colleges as fees. In the online mode of teaching the expenses are less.Some students are of the view that online teaching is suitable for them on the ground of saving money. If they stay in college hostels, they must pay huge amount. Instead they can attend online classes sitting in their 
houses. Time is also an important factor. Many students travel either by college buses or by public transportation and allot their considerable time in travelling. If they attend online classes, they can save time, devote some valuable time with members of their family and can pursue vocational courses. Another advantage is, when students are unable to attend online classes, or when they cannot understand the topic, they can watch recorded videos again and again till they understand.

The slogan 'Stay home, stay safe' applies for students who participate in online classes. When they attend classes, they may be affected by virus. Of course, the authorities follow all the standard operational procedures announced by the Home Ministry from time to time. But sometimes, how careful they are, they may be attacked by the virus without their knowledge.

If students want to enjoy the benefit of online teaching, they must follow two things scrupulously, self-discipline and self-control. They must attend classes regularly and answer the questions honestly. They must not get diverted by any distractions.

But there are equally disadvantages like network problems, indiscipline missing of direct contact with teachers. A professor of an Engineering College has noticed that twenty students out of sixty have expressed their inability to follow online teaching because of network problems. Where is the solution to this problem?

In an article published in IndiaToday Dr. Kulneet Suri, Sr. Director at the Institute of Management Studies Noida, says "Intoday's competitive world application-based learning is of primary importance and only traditional classroom can provide that. Be it learning to handle an instrument, carrying out a chemical experiment, or sharpening your public speaking skill, the level of learning is much more advanced when you do them in the real world". He also says," Virtual learning may be well suited for adult students who have to take care of their expenses along with schooling but for young pupils, there can be no other alternative to classroom training".

So, the authorities should consider all these things. They should not encourage online teaching till normalcy is restored at least for primary and secondary school children. It would be wise on the part of the administration to take all possible and reasonable steps to streamline the academic year without conducting online classes at least for little children.

It is apt to conclude this paper with a saying by Ian Lamont, a journalist He says" The most effective learning takes place in the classroom where you can easily raise your hand, engage in spontaneous discussions with classmates and faculty, turn to the person next to you to ask for clarification, or approach the professor after class or during office hours to ask questions, or exchange viewpoint, in a way that practically guarantees, an instant response, and is not constrained by typing software interfaces or waiting for a response".

\section{References}

[1] Cooperman, L. (2017). The Art of Teaching Online: How to Start and How to Succeed as an Online Instructor. Netherland: Chandos Publishing.

[2] E.E., H. (1970). Evolving Instruction. New York: Macmillan Co.

[3] Harasim, L. (2017). Learning Theory and Online Technologies. Canada: Routledge.

[4] Hyman, R. T. (1971). Contemporary Thought on teaching. New Jersy: PrenticeHall.

[5] Singh, A. (. (1993). The craft of Teaching. Delhi: Kanishka Publishers.

[6] Stephanie Smith Budhai, K. S. ( 2016). Best Practices in Engaging Online Learners Through Active and Experiential Learning Strategies. Routledge.

[7] Thelen, H. (1967). Classroom Grouping for teaching Ability. New York: Wiley.

[8] Tobin, J. M. (2015). Evaluating Online Teaching - Best Practices. San Francisco: Jossey-Bass. 